\title{
The effect of frozen storage on chemical and sensory quality of horse mackerel (Trachurus trachurus) coated whey protein isolate enriched with thyme essential oil
}

\section{Dondurarak depolamanın kekik esansiyel yağı ile zenginleştirilmiş peynir altı suyu protein izolatı ile kaplanan istavrit (Trachurus trachurus)'in kimyasal ve duyusal kalitesine etkisi}

\author{
Bahar Tokur ${ }^{1 *}$ (D) Elif Tuğçe Aksun 2 (D) \\ ${ }_{1}^{1}$ Department of Fisheries Technology Engineering, University of Ordu, Fatsa, Ordu, Turkey \\ 2 Department of Fishing and Fish Processing Technology, Faculty of Fisheries, Cukurova University, 01330 Balcali, Adana, Turkey \\ *Corresponding author: baharorhun@gmail.com
}

How to cite this paper:

Tokur, B. \& Aksun, E.T. (2018). The effect of frozen storage on chemical and sensory quality of horse mackerel (Trachurus trachurus) coated whey protein isolate enriched with thyme essential oil. Ege Journal of Fisheries and Aquatic Sciences, 35(3), 295-304. DOI:10.12714/egejfas.2018.35.3.09

\begin{abstract}
In this study, the effectiveness of whey protein isolate (WPI) and WPI enriched thyme essential oil coating to improve the quality of horse mackerel during frozen storage at $-18{ }^{\circ} \mathrm{C} \pm 2$ were evaluated for nine month. Whey protein isolate without thyme essential oil (WPIO) and three different proportion thyme essential oil ( 3,5 and $7 \%$, v/v) in whey protein isolate (WPI3, WPI5 and WPI7) coating solutions were applied to horse mackerel. As a control, non-coated and distillated water coating (DW) horse mackerel were used. The results showed that the lowest peroxide value (PV) (meq of peroxide oxygen $\mathrm{kg}-1$ ) and thiobarbutiric acid value (TBA) (mg malonaldehyde/kg muscle) were determined in WPI coatings enriched with $3 \%$ thyme essential oil treated group $(p<0.05)$ while the highest PV and TBA values were determined in WPI coatings enriched with $5 \%$ and $7 \%$ thyme essential oil treated groups $(p<0.05)$. Among the treatment, DW and the WPI coatings enriched with $7 \%$ thyme oil gave significantly higher protein solubility than other treatments during frozen storage $(p<0.05)$. Electrophoretic studies in the presence and absence of $\beta$-mercaptoethanol showed that high molecular weight polymers via non-disulfide and disulfide cross-linking occurred in the horse mackerel proteins extracted in $5 \% \mathrm{NaCl}$ in all groups during frozen storage. Sensory assessment showed that the horse mackerel coated WPI enriched with 5 and $7 \%$ thyme essential oil could not be stored for more than 9 months.
\end{abstract}

Keywords: Whey protein isolate, coating, thyme essential oil, frozen storage, horse mackerel

Öz: Bu çalışmada, $18 \pm 2{ }^{\circ} \mathrm{C}$ 'de dondurularak depolanan istavritin kalitesini geliştirmek amacıyla peynir altı suyu protein izolatı (WPI) ve kekik esansiyel yağı ile zenginleștirimiş WPI kaplamanın etkisi 9 aylık süre için değerlendirilmișțir. İstavritlere, kekik esansiyel yağı ilave edilmemiş (WPIO) ve üç farklı oranlarda kekik esansiyel yağı ( $\% 3, \% 5$ ve \%7, v/v) içeren peynir altı suyu protein izolattı (WPI3,WPI5 ve WPI7) kaplama solüsyonu uygulanmıştır. Kontrol grubu olarak, herhangi bir kaplama uygulanmayan ve saf su glazeli (DW) istavritler kullanılmıştı. Araştırmanın sonucunda, en düşük peroksit (PV) ve tiyobarbitürik asit (TBA) değerleri $\% 3$ oranında kekik esansiyel yağı uygulanan grupta bulunurken $(p<0.05)$, en yüksek PV ve TBA değerleri $\% 5$ ve $\% 7$ oranında kekik esansiyel yağı uygulanan gruplarda bulunmuştur $(\mathrm{p}<0.05)$. Gruplar arasında DW ve \%7 oranında kekik esansiyel yağı uygulananlar, dondurularak depolama boyunca diğer gruplara göre önemli oranda daha yüksek protein çözünürlüğüne sahip olmuştur $(p<0.05)$. $\beta$-mercaptoethanol varlığında ve yokluğunda yapılan elektroforetik çalışmalar sonucunda, dondurarak depolama boyunca tüm gruplarda disülfit olan ve disülfit olmayan çapraz bağların oluşmasıyla yüksek moleküler ağırlıkı polimerlerin $\% 5$ $\mathrm{NaCl}$ 'da ekstrakte edilen istavrit proteinlerinde meydana geldiği görülmüştür. Duyusal değerlendirmeye göre, $\% 5$ ve $\% 7$ kekik esansiyel yağı ile zenginleştirimiş WPI kaplı istavritlerin dokuz aydan daha uzun süre dondurularak depolanamayacağı belirlenmiştir.

Anahtar kelimeler: Peynir altı suyu protein izolatı, kaplama, kekik esansiyel yağı, dondurularak depolama, istavrit

\section{INTRODUCTION}

Freezing, one of the oldest methods of food preservation, is still the most common and effective technique for providing a significantly extended shelf life. Although freezing and frozen storage are able to control or decrease biochemical changes, degradation of lipid and protein cannot terminate, which causes deteriorative quality changes in flavour, odour and texture.
Application of edible film and coatings are a good alternative for suppressing quality changes during frozen storage by, for instance, delaying moisture, aroma and oil loss or gain and reducing lipid oxidation. They also can be used as a potential biopolymer for carrying and holding antioxidants and antimicrobials at food surfaces (Janjarasskul and Krochta, 
2010).

Edible films and coatings are usually made from proteins, lipids and polysaccharides. One consisting of protein, whey protein isolate (WPI) created by filtering milk protein, is of particular interest for coating owing to its excellent oxygen, aroma and oil barriers: it has good mechanical properties, excellent gloss and transparency. Although the use of edible coatings made of different types of biodegradable polymers during frozen fish storage has been researched (Duan et al.,2010; Kilincceker et al.,2009; Sathivel et al., 2007), few studies have been published to date about whey protein isolate coating (Motalebi et al.,2010;Stuchell and Krochta, 1995; Rodriguez-Turienzo et al., 2011).

Bioactive edible coatings can be enriched with plant essential oils (EOs), thus further improving food quality and safety (Ojagh et al.,2009). Thyme EOs have phenolic compounds responsible for the high antioxidant capacity due to their biologically active compounds such as carvacrol and thymol and offer a promising alternative to synthetic antioxidants in minimizing rancidity (Altiok et al.,2010;Burt et al., 2005). The protective effect of thyme oil against lipid oxidation in frozen seafood has been thoroughly reviewed (Çoban, 2012; Erkan and Bilen, 2010). However, there is no information about the use of edible coatings enriched with essential oil on frozen horse mackerel.

Horse mackerel (Trachurus trachurus), a semi-pelagic fish distributed mainly over the continental shelf of the Northeast Atlantic from Norway to Senegal, and in the Mediterranean and Black Seas, has recently attracted great commercial attention because of its moderate price and large quantities captured (Aubourg et al., 2004; Özden, 2010). Horse mackerel is highly prone to oxidation because it contains high levels of $\omega 3$ polyunsaturated fatty acids (PUFAs), which can have a negative effect on the commercial value (Gimenez et al.,2011). The aim of this work was to determine the effects of whey protein isolate coatings enriched with different concentrations of thyme essential oil on chemical and sensory quality of horse mackerel during frozen storage at $-18 \pm 2{ }^{\circ} \mathrm{C}$.

\section{MATERIALS AND METHODS}

\section{Materials}

Horse mackerel (Trachurus trachurus), $13.31 \pm 0.68 \mathrm{~cm}$ length and $17.36 \pm 1.59 \mathrm{~g}$ weight, were caught in eastern Black Sea Coast in December and transported in crushed iced till arrival to the laboratory within 10 hours. The whey protein isolate (WPI) was obtained from Davisco Foods International Inc. (BIPRO, La Sueur, MN, USA). According to the manufacturer, the composition of the product was $97.9 \%$ protein (dry weight basis), $4.6 \%$ moisture, $1.8 \%$ ash, $0.2 \%$ fat and $6.9 \mathrm{pH}$ (10\%@20C). Candelilla wax was supplied from Strahl and Pitsch Inc. (West Babylon, N.Y., U.S.A.). Food grade glycerol and $\mathrm{NaOH}$ were purchased from a commercial food ingredient grocery store in Istanbul. Commercial thyme oil (Karden, Kardelen Tarım Ürünleri Ltd., Ankara) was supplied from a local herbal store. All chemicals and reagents used were of analytical grade and purchased from either Merck (Darmstadt, Germany) or Sigma (St. Louis, MO).

\section{Methods}

Preparation of coating solutions and application to fish

The WPI coatings solutions were prepared as described by Seydim and Sarikus (2006). Whey protein isolate ( $5 \% \mathrm{w} / \mathrm{v})$ was dissolved in distilled water, and glycerol $(5 \% \mathrm{w} / \mathrm{v})$ was added. The $\mathrm{pH}$ was adjusted to 8.0 with $2 \mathrm{~N} \mathrm{NaOH}$. The solutions were heated to $90 \pm 2{ }^{\circ} \mathrm{C}$ while being stirred continuously. Candelilla wax $(0.8 \% \mathrm{w} / \mathrm{v})$ was added during heating. The coating solutions were filtered through a layer of cheesecloth. Thyme oil $3 \%, 5 \%$, and $7 \%$ ratios $(\mathrm{v} / \mathrm{v})$ were added to the coating solutions. After homogenizing for two minutes using an Ultraturax homogenizer (IKA, Germany), the solutions were cooled to room temperature for 1.5 hours. Vacuum was applied for 30 minutes to remove dissolved air in the solutions.

After the fish arrived at the laboratory, A total of $48 \mathrm{~kg}$ of fresh horse mackerel ( $8 \mathrm{~kg}$ in each group) were washed with tap water and frozen at $-80{ }^{\circ} \mathrm{C}$ for overnight storage. The coatings were applied after freezing. They were divided into six groups. One was directly packaged in polyethylene zip-lock freezer bags and stored at $-18^{\circ} \mathrm{C}$ and considered as the noncoating group (Control). Others were dipped in distillated water (DW), whey protein isolate coating solution without thyme oil (WPI0) and WPI coating solution enriched with three different concentrations of thyme oil (WPI3\%, WPI5\% and WPI7\%). The fish were dipped in the coating solution enriched with different concentrations of thyme essential oil for 30 seconds, drained for 15 seconds, packed in zip-lock freezer bags (RodriguezTurienzo et al., 2011) and then stored at $-18 \pm 2{ }^{\circ} \mathrm{C}$ for nine months.

\section{Proximate analyses}

The crude protein was determined by Kjeldahl's method (AOAC, 1984). Lipids were extracted by the method of Bligh and Dyer (1959). The moisture content (AOAC, 1990) and crude ash content (AOAC, 1998) were determined in an oven at $103^{\circ} \mathrm{C}$ and $550^{\circ} \mathrm{C}$ respectively until the weight became constant.

Gas chromatography mass spectrometry (GC/MS) analyses of thyme essential oil

Thyme EO was analyzed using gas chromatography mass spectrometry (GC/MS). GC/MS analyses were performed on a Perkin Elmer Clarus 500 capillary gas chromatograph directly coupled to the mass spectrometer system (Japan). SGE non polar fused silica capillary column $(60 \mathrm{~m} \times 0.25 \mathrm{~mm}$, ID. BPX5 $0,25 \mathrm{um}, \mathrm{USA}$ ) was used under the following conditions: oven temperature program from $60^{\circ} \mathrm{C}(10 \mathrm{~min})$ to $250^{\circ} \mathrm{C}$ at $4^{\circ} \mathrm{C} / \mathrm{min}$, and the final temperature kept for $10 \mathrm{~min}$; injector temperature $220^{\circ} \mathrm{C}$; helium as carrier gas, flow rate $1.5 \mathrm{~mL} / \mathrm{min}$. The volume of injected sample was $1 \mu \mathrm{l}$ of diluted oil in hexane; splitless injection technique; ionization energy $70 \mathrm{eV}$, in the electronic 
ionization (El) mode; ion source temperature $200^{\circ} \mathrm{C}$; scan mass range of $\mathrm{m} / \mathrm{z} 35-425$ and interface line temperature $250^{\circ} \mathrm{C}$. The constituents of essential oils were identified and calculated in relation to the retention time of a series of alkanes (C4- C28) as reference products and the similarity of their mass spectra with those gathered in the NIST-MS and WILEY-MS library, or reported in the literature. As a result of GC-MS analysis, the main components in the commercial thyme oil showed that it contained carvacrol $(78.12 \%)$, transCaryophyllene (4.27\%), beta Bisabolene (3.34\%), dinopol NOP $(2.86 \%)$, thymene $(1.91 \%)$, gamma terpinene $(1.59 \%)$ and caryophyllene oxide $(1.18 \%)$.

\section{Chemical analyses}

Peroxide value $(\mathrm{PV})$, expressed in milliequivalents of peroxide oxygen $\mathrm{kg}-1$ of fat, was determined according to AOCS (1994). The value of thiobarbituric acid (TBA) was determined according to the method of Tarladgis et al. (1960), and results were expressed as TBA value, mg malonaldehyde/ $\mathrm{kg}$ muscle.

The protein solubility was measured according to Dyer et al. (1950). $0.5 \mathrm{~g}$ fish muscle were homogenized with 5 $\% \mathrm{NaCl}$ solution using a homogenizer (Ultra-turrax, Ika T8, 1KA Labortechnik, Staufen, Germany) for 1 min at speed 5 (20.000 $\mathrm{rpm})$ in ice. Homogenate was then centrifuged at $5.000 \times \mathrm{g}$ at $4^{\circ} \mathrm{C}$ for 20 min using a Hettich Rotina $420 \mathrm{R}$ bench centrifuge (DJB Labcare Ltd., Buckinghamshire, UK). The supernatant was used for SDS-PAGE and for the determination of protein concentrations. The protein content of the extract was determined by the Lowry method (Lowry et al., 1951). Bovine serum albumin was used as a standard. Percentage of soluble protein was expressed as the ratio of the quantity of soluble protein after frozen storage to that of original soluble protein from fresh samples.

Sodium dodecyl sulfate (SDS)-polyacrylamide gel electrophoresis was used to monitor polymerization and fragmentation of proteins using a BioRad Mini vertical gel electrophoresis (Laemmli, 1970). To determine the polymerization of myosin heavy chain $(\mathrm{MHC})$, samples prepared with sample buffer with and without $\beta$ mercaptoethanol were compared. SDS-PAGE was performed in a $10 \%(\mathrm{w} / \mathrm{v})$ resolving gel and $4 \%(\mathrm{w} / \mathrm{v})$ stacking gel run at 240 volt for 40 minute. Gels were stained overnight with $0.025 \%$ (w/v) Coomassie blue R-250 in 40\% aqueous methanol and 7\% acetic acid. Destaining was achieved by sequential treatment of gels first with an aqueous solution consisting of $40 \%$ methanol and $7 \%$ acetic acid, followed by $5 \%$ aqueous methanol and $7 \%$ acetic acid, and finally distilled water. Protein molecular weight standards were obtained from Sigma Ltd. (St. Louis, MO) consisted of myosin (200 kDa), $\beta$-galactosidase (116 kDa), phosphorylase b (97 kDa) bovine serum albumin (66 $\mathrm{kDa}$ ), glutamic dehydrogenase (55 kDa), ovalalbumin (45 kDa) and glyceraldehydes-3-phosphate dehydrogenase (29 kDa).

\section{Sensory Analysis}

For sensory analysis, each assessment was carried out by a six to eight trained panelists. Sensory analyses of fish (appearance, odour, flavour and texture) were assessed according to the method of Paulus et al. (1979) with modification. modification. Fish were cooked in a microwave oven for $3 \mathrm{~min}(450 \mathrm{w})$ and then served to the panelists to assess. A hedonic scale from 9 to 1 was used to evaluate frozen horse mackerel. A score of 9 represents 'very good quality', a score of 7-8, 'good quality', a score of 5-6 'acceptable', while a score of 1-4 was regarded as 'bad or unacceptable'.

\section{Statistical analyses}

Experiment statistics were performed using SPSS for Windows software program (SPSS 18.0 for Windows). The results were expressed as the mean and standard deviation. Data analysis for each treatment was carried out in triplicate and the mean of each sample for each group was analysed three times. One-way analysis of variance (ANOVA) was used to check the variance homogeneity, normality and compared by using Duncan's multiple range test at 95\% confidence interval. The treatment effect was performed using Duncan's multiple range test in the general linear models procedure (GLM). Sensory analyze was performed using non-parametric test and differences between in groups were evaluated analysis of variance.

\section{RESULTS AND DISCUSSION}

\section{Proximate analyses}

The moisture, lipid, crude protein and crude ash content of raw horse mackerel were found to be $76.4 \pm 0.64 \%, 6.86$ $\pm 0.12 \%, 21.74 \pm 0.48 \%$ and $1.22 \pm 0.03 \%$, respectively. The proximate composition of the horse mackerel showed similarities to the findings of Bandarra et al. (2001) and Vareltzis et al. (1997) with little differences. However, some researchers have found different results in lipid content of horse mackerel (Aubourg et al., 2002, Aubourg et al.,2004; Boran and Karaçam, 2011). These differences may be related to size, food, migration and sexual changes and geographic region (Bandarra et al., 2001; Losada et al., 2005; Çelik, 2008; Boran and Karaçam, 2011). The moisture, lipid, crude protein and crude ash content of horse mackerel coated with WPI were found to be $73.70 \pm 1.04 \%, 5.86 \pm 0.06 \%$ and $24.48 \pm 0.45 \%$ and $1.14 \pm 0.05 \%$, respectively. There was an apparent net increase in protein content of horse mackerel coated with WPI compared to the raw ones but a decrease in the moisture, lipid and crude ash. The increasing the crude protein content in it was related to coating of whey protein isolate. The decreasing the moisture, lipid and crude ash can be explained by the increase in the protein content.

\section{Chemical quality}

Peroxide value (PV) of horse mackerel coated whey protein isolate enriched with thyme oil is given in Table1. 
Table 1. PV (meq of peroxide oxygen $\mathrm{kg}-1$ ) of horse mackerel coated whey protein isolate enriched with thyme oil ${ }^{1,2,3}$

\begin{tabular}{lllllll}
\hline Months & Control & DW & WPIO & WPI3 & WPI5 & WPI7 \\
\hline 0 & $0.55 \pm 0.03^{\mathrm{c} 1}$ & $0.44 \pm 0.01^{\mathrm{b} 1}$ & $0.41 \pm 0.01^{\mathrm{ab} 1}$ & $0.34 \pm 0.03^{\mathrm{a} 1}$ & $0.84 \pm 0.06^{\mathrm{d} 1}$ & $0.97 \pm 0.02^{\mathrm{e} 1}$ \\
1 & $0.55 \pm 0.01^{\mathrm{c} 1}$ & $0.45 \pm 0.03^{\mathrm{b} 1}$ & $0.59 \pm 0.01^{\mathrm{d} 2}$ & $0.39 \pm 0.02^{\mathrm{a} 1}$ & $0.89 \pm 0.02^{\mathrm{e} 1}$ & $0.96 \pm 0.03^{\mathrm{f} 1}$ \\
2 & $1.23 \pm 0.03^{\mathrm{b} 2}$ & $1.11 \pm 0.03^{\mathrm{ab} 2}$ & $1.35 \pm 0.01^{\mathrm{bc} 3}$ & $0.71 \pm 0.55^{\mathrm{a} 12}$ & $1.49 \pm 0.02^{\mathrm{bc} 2}$ & $1.71 \pm 0.03^{\mathrm{c} 2}$ \\
3 & $1.23 \pm 0.03^{\mathrm{c} 2}$ & $1.14 \pm 0.04^{\mathrm{b} 2}$ & $1.34 \pm 0.01^{\mathrm{d} 3}$ & $1.02 \pm 0.02^{\mathrm{a} 2}$ & $1.44 \pm 0.02^{\mathrm{e} 2}$ & $1.71 \pm 0.02^{\mathrm{c} 2}$ \\
4 & $3.63 \pm 0.02^{\mathrm{c} 3}$ & $3.54 \pm 0.02^{\mathrm{b} 3}$ & $3.67 \pm 0.02^{\mathrm{d} 4}$ & $3.46 \pm 0.01^{\mathrm{a} 3}$ & $5.18 \pm 0.02^{\mathrm{e} 3}$ & $5.29 \pm 0.02^{\mathrm{f} 3}$ \\
5 & $6.38 \pm 0.03^{\mathrm{b} 4}$ & $6.53 \pm 0.02^{\mathrm{c} 4}$ & $6.54 \pm 0.02^{\mathrm{c} 5}$ & $6.34 \pm 0.01^{\mathrm{a} 4}$ & $6.96 \pm 0.02^{\mathrm{d} 4}$ & $7.03 \pm 0.02^{\mathrm{e} 4}$ \\
6 & $7.06 \pm 0.02^{\mathrm{b} 5}$ & $7.05 \pm 0.03^{\mathrm{b} 5}$ & $7.16 \pm 0.02^{\mathrm{c} 6}$ & $6.97 \pm 0.02^{\mathrm{a} 5}$ & $7.82 \pm 0.02^{\mathrm{d} 5}$ & $7.96 \pm 0.03^{\mathrm{e} 5}$ \\
7 & $11.03 \pm 0.02^{\mathrm{a} 6}$ & $10.98 \pm 0.02^{\mathrm{a} 6}$ & $11.04 \pm 0.02^{\mathrm{a} 7}$ & $11.27 \pm 0.44^{\mathrm{a} 6}$ & $11.21 \pm 0.04^{\mathrm{a} 6}$ & $11.37 \pm 0.03^{\mathrm{a} 6}$ \\
8 & $14.04 \pm 0.02^{\mathrm{b} 7}$ & $14.07 \pm 0.02^{\mathrm{b} 7}$ & $14.08 \pm 0.02^{\mathrm{b} 8}$ & $14.00 \pm 0.01^{\mathrm{a} 7}$ & $14.81 \pm 0.03^{\mathrm{c} 7}$ & $14.98 \pm 0.01^{\mathrm{d} 7}$ \\
9 & $16.12 \pm 0.01^{\mathrm{b} 8}$ & $16.15 \pm 0.03^{\mathrm{b} 8}$ & $16.30 \pm 0.06^{\mathrm{c} 9}$ & $16.01 \pm 0.01^{\mathrm{a} 8}$ & $16.61 \pm 0.01^{\mathrm{d} 8}$ & $16.77 \pm 0.05^{\mathrm{e} 8}$ \\
GLM & $6.18^{\mathrm{b}}$ & $6.15^{\mathrm{b}}$ & $6.25^{\mathrm{c}}$ & $6.0530^{\mathrm{a}}$ & $6.7253^{\mathrm{d}}$ & $6.8739 \mathrm{e}$
\end{tabular}

1 Values are mean \pm standard deviation.

2 Means within the same column $(1,9)$ and the same row $(a, f)$ with different letters are different $(P<0.05)$.

${ }^{3}$ GLM, genel linear model DW, distillated water; WPI0, whey protein isolate coating without thyme oil; WPI3, whey protein isolate coating with $3 \%$ thyme oil; WPI5, whey protein isolate coating with $5 \%$ thyme oil; WPI7, whey protein isolate coating with $7 \%$ thyme oil

Table 2. Thiobarbutiric acid (TBA) (mg malonaldehyde / $\mathrm{kg}$ muscle) value of horse mackerel coated whey protein isolate enriched with thyme oil $1,2,3$

\begin{tabular}{cllllll}
\hline Months & Control & DW & WPI0 & WPI3 & WPI5 & WPI7 \\
\hline 0 & $0.56 \pm 0.01^{\mathrm{c} 1}$ & $0.59 \pm 0.01^{\mathrm{d} 1}$ & $0.49 \pm 0.00^{\mathrm{b} 1}$ & $0.46 \pm 0.02^{\mathrm{a} 1}$ & $0.46 \pm 0.01^{\mathrm{e} 1}$ & $0.47 \pm 0.00^{\mathrm{f} 1}$ \\
1 & $0.73 \pm 0.01^{\mathrm{d} 2}$ & $0.64 \pm 0.00^{\mathrm{c} 2}$ & $0.56 \pm 0.00^{\mathrm{a} 2}$ & $0.56 \pm 0.00^{\mathrm{a} 2}$ & $0.62 \pm 0.00^{\mathrm{b} 2}$ & $0.61 \pm 0.02^{\mathrm{b} 2}$ \\
2 & $0.73 \pm 0.01^{\mathrm{d} 2}$ & $0.65 \pm 0.01^{\mathrm{c} 3}$ & $0.56 \pm 0.00^{\mathrm{a} 2}$ & $0.57 \pm 0.00^{\mathrm{a} 2}$ & $0.62 \pm 0.00^{\mathrm{b} 2}$ & $0.62 \pm 0.00^{\mathrm{b} 2}$ \\
3 & $0.85 \pm 0.04^{\mathrm{a} 3}$ & $0.87 \pm 0.00 \mathrm{a}^{\mathrm{b} 4}$ & $0.86 \pm 0.00^{\mathrm{ab} 3}$ & $0.85 \pm 0.00^{\mathrm{a} 3}$ & $0.88 \pm 0.00^{\mathrm{b} 3}$ & $0.92 \pm 0.01^{\mathrm{c} 3}$ \\
4 & $0.96 \pm 0.00^{\mathrm{b} 4}$ & $0.96 \pm 0.00^{\mathrm{b} 5}$ & $0.87 \pm 0.01^{\mathrm{a} 4}$ & $0.86 \pm 0.00^{\mathrm{a} 3}$ & $1.04 \pm 0.02^{\mathrm{c} 4}$ & $1.10 \pm 0.00^{\mathrm{d} 4}$ \\
5 & $1.11 \pm 0.00^{\mathrm{c} 5}$ & $1.12 \pm 0.00^{\mathrm{d} 6}$ & $0.96 \pm 0.00^{\mathrm{b} 5}$ & $0.88 \pm 0.00^{\mathrm{a} 4}$ & $1.17 \pm 0.00^{\mathrm{e} 5}$ & $1.22 \pm 0.00^{\mathrm{f} 5}$ \\
6 & $1.52 \pm 0.02^{\mathrm{c} 6}$ & $1.48 \pm 0.00^{\mathrm{b} 7}$ & $1.40 \pm 0.00^{\mathrm{a} 6}$ & $1.40 \pm 0.00^{\mathrm{a} 5}$ & $1.56 \pm 0.00^{\mathrm{d} 6}$ & $1.57 \pm 0.00^{\mathrm{d} 6}$ \\
7 & $1.56 \pm 0.00^{\mathrm{a} 7}$ & $1.58 \pm 0.01^{\mathrm{b} 8}$ & $1.56 \pm 0.00^{\mathrm{a} 7}$ & $1.56 \pm 0.00^{\mathrm{a} 6}$ & $1.80 \pm 0.00^{\mathrm{c} 7}$ & $1.97 \pm 0.00^{\mathrm{d} 7}$ \\
8 & $3.51 \pm 0.05^{\mathrm{b} 8}$ & $3.48 \pm 0.00^{\mathrm{b} 9}$ & $3.31 \pm 0.00^{\mathrm{a} 8}$ & $3.31 \pm 0.00^{\mathrm{a} 7}$ & $3.43 \pm 0.12^{\mathrm{b} 8}$ & $3.70 \pm 0.00^{\mathrm{c} 8}$ \\
9 & $3.46 \pm 0.03^{\mathrm{b} 9}$ & $3.48 \pm 0.00^{\mathrm{b} 9}$ & $3.31 \pm 0.00^{\mathrm{a} 8}$ & $3.31 \pm 0.00^{\mathrm{a} 7}$ & $3.75 \pm 0.00^{\mathrm{c} 8}$ & $3.84 \pm 0.03^{\mathrm{d} 8}$ \\
GLM & $1.499277^{\mathrm{d}}$ & $1.483677^{\mathrm{c}}$ & $1.386586^{\mathrm{b}}$ & $1.375003^{\mathrm{a}}$ & $1.549548^{\mathrm{e}}$ & $1.625110^{\mathrm{f}}$ \\
\hline
\end{tabular}

1 Values are mean \pm standard deviation.

${ }^{2}$ Means within the same column $(1,9)$ and the same row $(a, f)$ with different letters are different $(P<0.05)$.

${ }^{3} \mathrm{GLM}$, genel linear model DW, distillated water; WPIO, whey protein isolate coating without thyme oil; WPI3, whey protein isolate coating with $3 \%$ thyme oil; WPI5, whey protein isolate coating with $5 \%$ thyme oil; WPI7, whey protein isolate coating with $7 \%$ thyme oil

The secondary lipid oxidation products were measured by means of thiobarbituric acid values (TBA) expressed as mg malonaldehyde $/ \mathrm{kg}$ muscle. As seen in Table 2, the initial TBA for the raw non-coated horse mackerel was found to be 0.55 $\mathrm{mg}$ malonaldehyde $/ \mathrm{kg}$ muscle. This value was higher than finding for horse mackerel by other researchers (Simeonidou et al.,1997; Aubourg et al., 2002; Aubourg et al.,2004). The reason of higher TBA value could be resulted from higher lipid content and iced storage (10 hour) before freezing (Aubourg et al., 2002). During frozen storage, TBA value showed an increase in all groups. WPI coating without thyme oil caused a decrease in TBA value when compared with noncoated and water coated groups. Similarly, coating with WPI solution/antioxidant overspray of King salmon have been found to be effective in controlling lipid oxidation after 77 days of frozen storage (Stuchell and Krochta,1995). Similar results have also been reported by Sathivel et al. (2007). As well as the present PV, the higher TBA value were found in samples coated WPI with enriched thyme oil $5 \%$ and $\% 7$ than others one, while the lowest TBA value was found in samples coated with WPI enriched with thyme oil $3 \%$. The prevention of lipid oxidation for frozen horse mackerel by using antioxidant have been reported previously (Aubourg et al., 2004). But antioxidant effect of thyme oil alone or combined with edible coating for 
horse mackerel during frozen storage did not evaluated before. It has been observed that $1 \%$ tyhme oil-treated chub mackerel (Erkan and Bilen, 2010) and rainbow trout (Çoban, 2012) had lower TBA value during frozen storage. In the current study, the using higher than $3 \%$ concentration thyme oil combined with WPI showed prooxidant acvtivity during frozen storage for horse mackerel. Several authors claim that a variety of testing systems is required when assessing the antioxidant potential of a substance, since a substance exhibiting high antioxidant activity in one system may have a pro-oxidant effect in another system (Laughton et al.,1989; Pearson et al., 1997.) Recent works indicate that high essential oils can have pro-oxidant effects (Mennen et al., 2005; Bakkali et al., 2008). Undeger et al. (2009) observed that high concentrations $(100 \mu \mathrm{M})$ carvacrol showed a pro-oxidant effect and high concentrations of thymol $(25 \mu \mathrm{M})$ increased DNA damage. This might explain why the higher thyme oil treated groups had a higher TBA value than the lower thyme oil treated groups.

Effect of whey protein isolate coating enriched with thyme oil on protein solubility (\%) in $5 \% \mathrm{NaCl}$ during frozen storage of horse mackerel is given in Table3.

Table 3. Protein Solubility (\%) of horse mackerel coated whey protein isolate enriched with thyme oil

\begin{tabular}{|c|c|c|c|c|c|c|}
\hline Months & Control & DW & WPIO & WPI3 & WPI5 & WPI7 \\
\hline 0 & $100^{1}$ & $100^{3}$ & $100^{2}$ & $100^{4}$ & $100^{3}$ & $100^{4}$ \\
\hline 1 & $96.80 \pm 0.14^{\mathrm{a} 3}$ & $103.50 \pm 0.17^{\mathrm{e} 1}$ & $102.76 \pm 0.22^{\mathrm{e} 1}$ & $103.12 \pm 0.12^{\mathrm{d} 1}$ & $101.63 \pm 0.07^{c 1}$ & $100.37 \pm 0.15^{\mathrm{b} 3}$ \\
\hline 2 & $97.02 \pm 0.24^{\mathrm{a} 3}$ & $101.37 \pm 0.28^{c 2}$ & $100.29 \pm 0.30^{\mathrm{b} 2}$ & $101.04 \pm 0.20^{c 2}$ & $101.13 \pm 0.13^{\mathrm{c} 2}$ & $104.48 \pm 0.16^{\mathrm{d} 1}$ \\
\hline 3 & $98.86 \pm 0.55^{a 2}$ & $101.31 \pm 0.21 \mathrm{~d} 2$ & $99.75 \pm 0.19 \mathrm{~b} 2$ & $100.43 \pm 0.14 c 3$ & $101.13 \pm 0.23^{\mathrm{d} 2}$ & $103.02 \pm 0.20^{\mathrm{e} 2}$ \\
\hline 4 & $86.02 \pm 0.17 \mathrm{a7}$ & $89.49 \pm 0.37^{\mathrm{b} 6}$ & $92.8 \pm 02.62^{c 3}$ & $93.43 \pm 0.25^{\mathrm{c} 4}$ & $88.14 \pm 0.14^{b 4}$ & $91.82 \pm 0.11^{c 5}$ \\
\hline 5 & $85.10 \pm 0.17^{a 8}$ & $88.47 \pm 0.14^{\mathrm{d} 7}$ & $90.31 \pm 0.24^{\mathrm{e} 4}$ & $87.88 \pm 0.15^{\mathrm{c} 67}$ & $87.22 \pm 0.32^{\mathrm{b} 5}$ & $91.18 \pm 0.17^{f 6}$ \\
\hline 6 & $93.98 \pm 0.19^{a 4}$ & $86.00 \pm 1.36^{\mathrm{d} 8}$ & $89.63 \pm 0.21^{\mathrm{e} 4}$ & $86.54 \pm 0.13^{c 8}$ & $87.28 \pm 0.19^{b 5}$ & $88.29 \pm 0.19^{99}$ \\
\hline 7 & $93.98 \pm 0.18^{\mathrm{e} 4}$ & $93.66 \pm 0.34 \mathrm{e} 4$ & $93.31 \pm 0.15^{\mathrm{d} 3}$ & $85.58 \pm 0.19 \mathrm{a} 9$ & $86.33 \pm 0.21^{\mathrm{b} 6}$ & $88.39 \pm 0.29 c 9$ \\
\hline 8 & $90.12 \pm 0.16^{d 6}$ & $92.20 \pm 0.29 \mathrm{e} 5$ & $86.28 \pm 0.17 \mathrm{a} 5$ & $88.12 \pm 0.12^{b 6}$ & $88.25 \pm 0.21^{b 4}$ & $89.55 \pm 0.17 \mathrm{c8}$ \\
\hline 9 & $91.62 \pm 0.38^{\mathrm{d} 5}$ & $91.88 \pm 0.15^{\mathrm{d} 5}$ & $85.58 \pm 0.17^{a 5}$ & $87.70 \pm 0.13^{b 7}$ & $87.51 \pm 0.16^{\mathrm{b} 5}$ & $90.05 \pm 0.11^{c 7}$ \\
\hline GLM & $93.35^{c}$ & $94.79^{a}$ & $94.15^{b}$ & $93.38^{c}$ & $92.86^{d}$ & $94.72^{\mathrm{a}}$ \\
\hline
\end{tabular}

${ }_{1}^{1}$ Values are mean \pm standard deviation.

${ }^{2}$ Means within the same column $(1,9)$ and the same row $(a, f)$ with different letters are different $(P<0.05)$.

${ }^{3} \mathrm{GLM}$, genel linear model DW, distillated water; WPIO, whey protein isolate coating without thyme oil; WPI3, whey protein isolate coating with $3 \%$ thyme oil; WPI5, whey protein isolate coating with $5 \%$ thyme oil; WPI7, whey protein isolate coating with $7 \%$ thyme oil

Protein solubility in $5 \%$ sodium chloride is used to characterize the degree of protein denaturation during frozen storage. In present study, protein solubility showed slightly decrease in all samples during frozen storage, similar to previous research on frozen horse mackerel (Undeland et al. 2003). There are published data indicating that a reduction in protein solubility during frozen storage was due to denaturation and aggregation of myofibrillar proteins in frozen fish (Geirsdottir et al., 2007). Hurling and McArthur (1996) studied frozen storage effects in cod and they found that myofibrillar protein solubility decreased from 70 to $22 \%$ of the total protein after 9 month storage at $-30^{\circ} \mathrm{C}$. They also indicated that decline in protein solubility was not caused by complete protein unfolding. Insolubilization of proteins during frozen storage is caused by formation of intermolecular hydrogen and/or hydrophobic bonds as well as disulfide bonds and ionic interaction (Akahane,1982). Montecchia et al.(1997) observed a slight increase in salt-soluble protein from hake after 15 day frozen storage at $-20^{\circ} \mathrm{C}$ followed by gradual decrease until the end of frozen storage. This slightly increased protein solubility might be caused by modifications of chemical groups, especially sulfhydryls. These changes would cause a transitory modification of molecular conformation as was suggested by in vitro experiments with carp actomyosin, myosin, and heavy meromyosin during short term frozen storage (Matsumoto, 1980). Comparison among the different treatments showed that coating process was helpful to protect the decrease in protein solubility till first three months (Aubourg et al., 2004). Among the treatment, DW and the WPI coated enriched with $7 \%$ thyme oil caused significantly higher protein solubility than other treatments during frozen storage $(p<0.05)$. However, the reduction of solubility did not change regularly. These fluctuations during frozen storage could be caused by interactions of proteins with other compounds such as fatty acids, decomposition products of lipids and amine compounds (Saeed and Howell 2002, Siddaiah et al., 2001).

\section{SDS-PAGE}

The electrophoretic profiles of the salt-soluble proteins extracted with $5 \% \mathrm{NaCl}$ from groups during frozen storage are shown in Figure 1. 

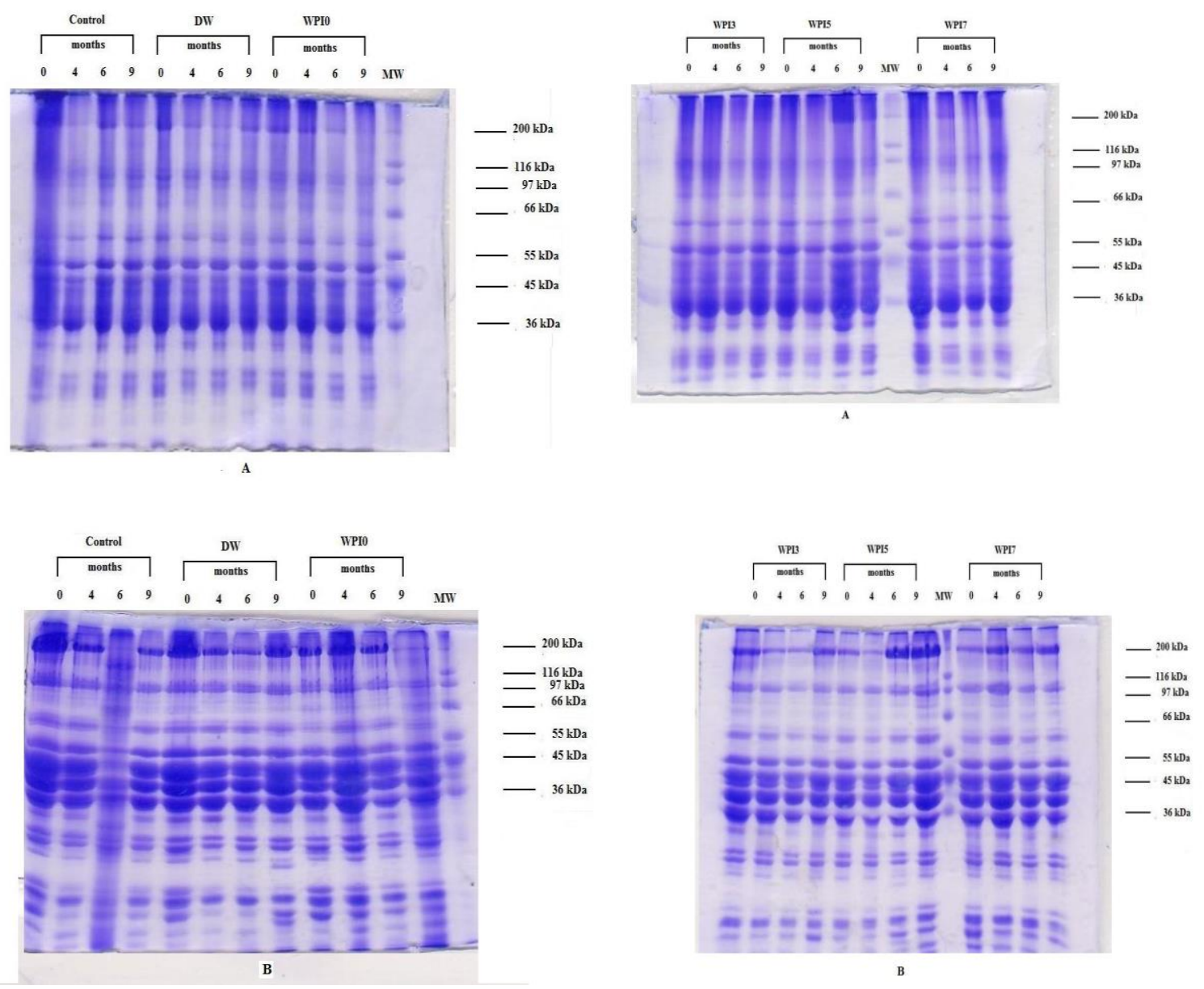

Figure 1. The electrophoretic profiles of the salt-soluble proteins extracted with $5 \% \mathrm{NaCl}$ from groups prepared without (A) and with $\beta$ mercaptoethanol (B) during frozen storage (DW, distillated water; WPI0, whey protein isolate coating without thyme oil; WPI3, whey protein isolate coating with $3 \%$ thyme oil; WPI5, whey protein isolate coating with $5 \%$ thyme oil; WPI7, whey protein isolate coating with $7 \%$ thyme oil, MW; molecular weight)

In this study, electrophoretic protein profiles in groups showed that the remarkable changes seen in the protein band around $200 \mathrm{kDa}$ in the absence of $\beta$-mercaptoethanol, indicating the absence of intermolecular disulfide bridges (Figure 2). In control, DW, WPI0 and WPI7, the intensity of this band decreased and/or increased throughout the frozen storage period of 9 months at $-18{ }^{\circ} \mathrm{C} \pm 2$, while it didn't seen in WPI3 from at the beginning of the storage to at the end of the storage and it didn't seen in WPI5 at the beginning four month and then appeared at month 6 and 9 . A double protein bands with molecular weight around $97 \mathrm{kDa}$ did not seen in the groups coated with thyme oil during storage. No significant differences were observed in other protein bands both between samples and during frozen storage. The protein profiles of samples treated with $\beta$-mercaptoethanol as reducing agent showed that there were many new bands in all samples when compare with the protein profiles of samples treated without $\beta$ mercaptoethanol during frozen storage. The new bands in the presence of reducing agent were attributed to polymerization high molecular weight via disulfide cross-linking (Le Blanc and
Le Blanch 1989). Formation of disulfide band also contributes to decrease in salt soluble protein during frozen storage (Owusu-Anash and Hultin 1986). In this study, the decrease in protein solubility observed in all samples during storage. These decreases could be resulted from cross-linking of protein (Keyvan et al., 2008). No significant differences between the electrophoretic profiles obtained within samples but the appearance of new bands of low moleculer weight $(<36 \mathrm{kDa})$ were seen in all samples during frozen storage. Main differences within groups were observed in control samples at six month of storage, the protein bands near $200 \mathrm{kDa}$ completely disappeared and new bands occurred near 116 and $97 \mathrm{kDa}$. At the interface of stacking and resolving electrophoresis gels, there was a proteins that did not penetrate the resolving gel, with a higher molecular weight than MHC, probably formed by the covalent linkage during frozen storage of muscle (Careche et al., 2002). In frozen fish, high molecular weight protein aggregate accumulated by hydrophobic interaction as well as by disulfide bonds and other covalent cross-links (Haard, 1992). 


\section{Sensory Quality}

The results of the sensory analyses of horse mackerel coated WPI enriched thyme oil during frozen storage are shown in Figure 2.

Panelists scored for brightness, color, odor, flavor, texture and general acceptability using a nine-point hedonic scale (1, dislike extremely to 9 , like extremely) for the assessment of sensory quality in samples. Results of the sensory evaluation obtained reveal that samples coated WPI enriched with $\% 5$ and $\% 7$ thyme oil showed the most marked changes $(p<0.05)$.

Significantly higher scores for color, odor and flavor were given to control, DW, WPI and WPI3, while WPI7 scored the significantly lowest for all parameters at the beginning of the storage $(p<0.05)$. When they stored longer, lower scores were given subsequently for all groups by the panelists. However, rancid flavor was estimated in samples coated WPI enriched with $5 \%$ and $7 \%$ thyme oil after nine month storage and the scores samples reached unacceptable levels. But, other groups received scores above the acceptability limit of 5 . These conclusions were also supported by the results for lipid quality analyses. The higher PV and TBA value were noticed at the later stage of storage days and these could be due to the production of lipid oxidation products, resulting in the unacceptable flavor. Similar trends were also observed in brightness, color, odor, texture and general acceptability (Figure 2). Similarly, Rodriguez-Turienzo et al. (2011) found that no significant differences $(p>0.05)$ between whey protein coated samples and controls and the sensory properties of salmon samples were not affected negatively by these coatings.
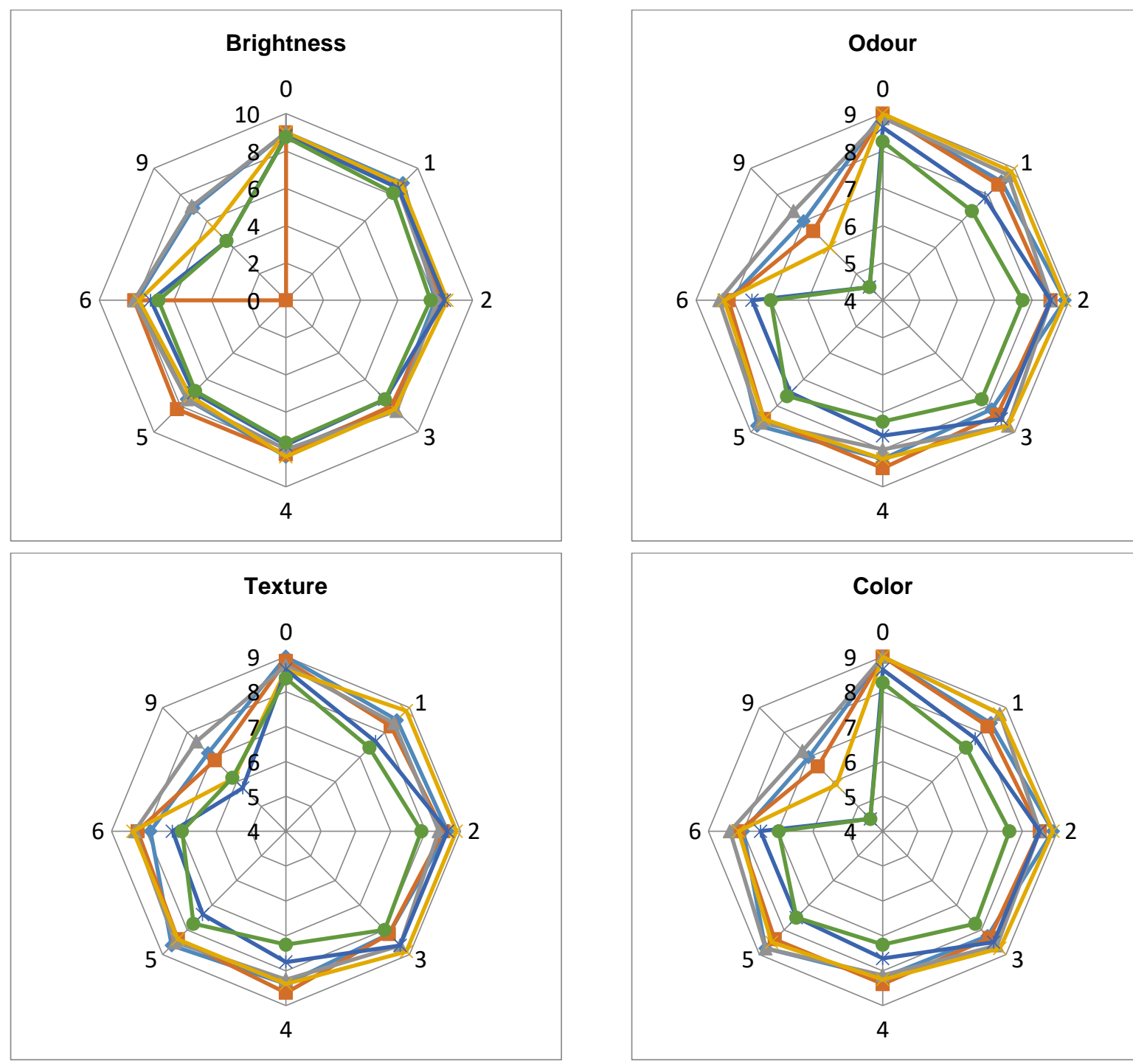

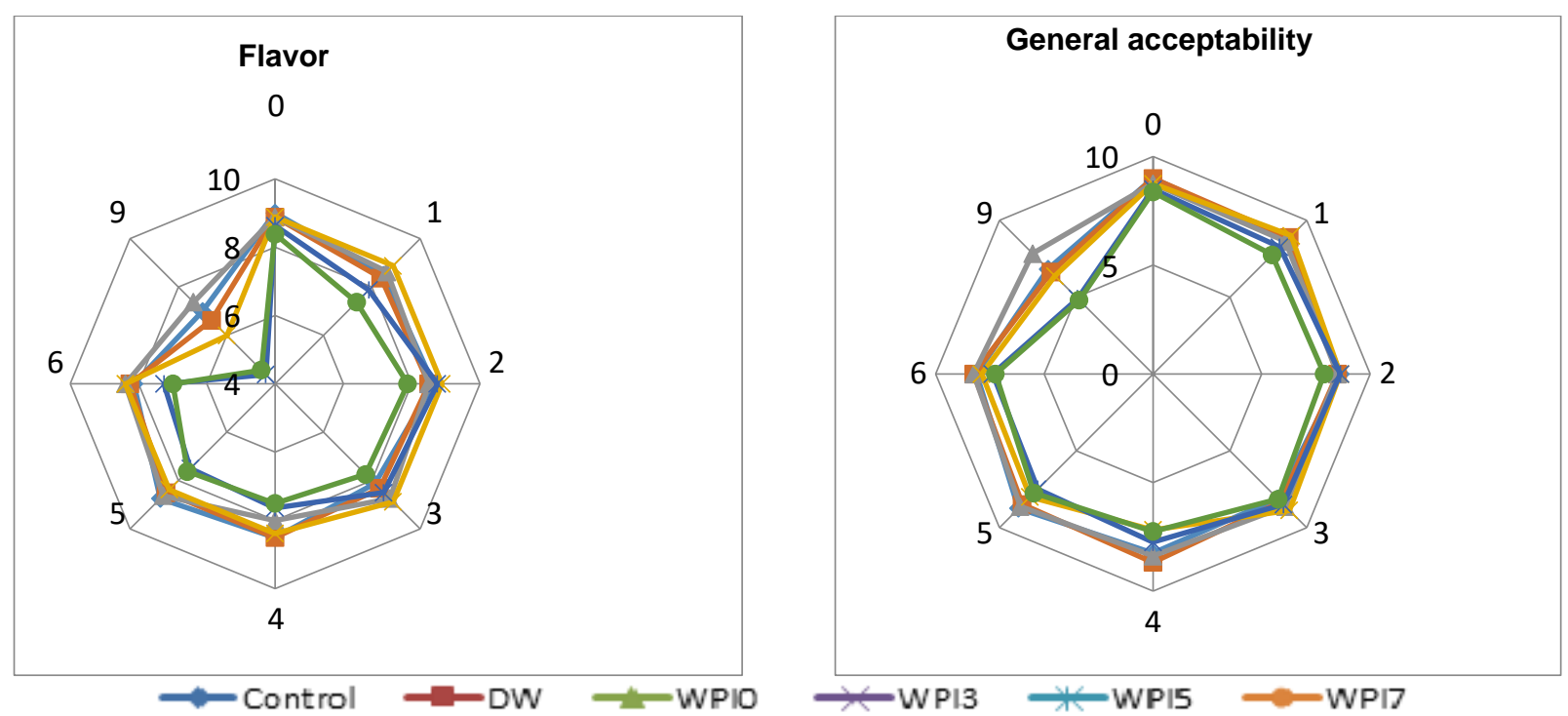

Figure 2- Sensory evaluation of horse mackerel coated whey protein isolate enriched with thyme oil during frozen storage

No significant $(p>0.05)$ effects of protein coating on $a^{*}, b^{*}$, and whiteness values for cooked pink salmon after 3 mo frozen storage were also reported by Sathivel (2005). The changing of brightness and color with addition of essential oil in edible coatings have been reported previously by researchers who claimed that addition of EOs in edible films may change the native color of edible films and the degree of change is concentration-dependent (Du et al., 2011; Rhim et al., 2000). Those results showed that the horse mackerel coated WPI enriched with 5 and $7 \%$ thyme oil could not be stored for more than 9 months.

\section{REFERENCES}

Akahane, T. (1982). Denaturation of Fish Muscle Proteins. Ph.D. thesis, Sophia Univ. Tokyo,Japan.195 pp

Altiok, D., Altiok, E. \& Tihminlioglu, F. (2010). Physical, antibacterial and antioxidant properties of chitosan films incorporated with thyme oil for potential wound healing applications. Journal of Materials Sciencematerials in Medicine, 21(7):2227-36. DOI: 10.1007/s10856-010-4065-x

AOCS. (1994). Official methods and recommended practices of the American Oil Chemists Society. American Oil Chemists Society, Champaign, IL

AOAC. (1984). Official Methods of Analysis, 14th Edn., Association of Analytical Chemists, Washington, DC

AOAC. (1990). Official methods of analyses of association of analytical chemist (15 ed.). Washington, DC

AOAC.(1998). Fish and other Marine Products: Official Method 938.08: Ash of Seafood. In P. Cunniff (Ed.). Official Methods of Analysis of AOAC International, Gaitherbury: USA.

Aubourg, S., Lehmann, I. \& Gallardo, J. (2002). Effect of previous chilled storage on rancidity development in frozen horse mackerel (Trachurus trachurus). Journal of the Science of Food and Agriculture, 82: 17641771. DOI: 10.1002/jsfa.1261

Aubourg, S., Lugasi, A., Hovari, J., Pineiro, J., Lebovics, V. \& Jaloczi, I. (2004). Damage inhibition during frozen storage of horse mackerel fillets by a

\section{CONCLUSION}

In conclusion, when thyme oil used higher concentration than $3 \%$, it can be play as a pro-oxidant for horse mackerel over the course of frozen storage and caused unacceptable level of fish. As a result of protein solubility and SDS-PAGE, whey protein isolate and enriching whey protein isolate with thyme oil showed no remarkable changes in protein quality.

\section{ACKNOWLEDGMENTS}

The authors want to thanks to Çukurova University, Scientific Research Projects Coordinating Office (ÇÜ-BAPSÜF2012BAP13) for supporting this research.

previous plant extract treatment. Journal of Food Science, 69:136-141. DOI: 10.1111/j.1365-2621.2004.tb15505

Bakkali, F., Averbeck, S., Averbeck, D. \& Idaomar, M. (2008). Biological effects of essential oils- a review. Food and Chemical Toxicology, 46:446-475. DOI: 10.1016/j.fct.2007.09.106

Bandarra, N.M., Batista, I., Nunes, M.L. \& Empis, J.M. (2001). Seasonal variation in the chemical composition of horse-mackerel (Trachurustrachurus). European Food Research Technology, 212: 535-539. DOI: $10.1007 / \mathrm{s} 002170100299$

Bligh, E.C. \& Dyer, W.J. (1959). A rapid method of total lipid extraction and purification. Canadian Journal of Biochemistry and Physiology, 37: 913917. DOI: 10.1139/059-099

Boran, G. \& Karacam., H. (2011). Seasonal changes in proximate composition of some fish species from the Black Sea. Turkish Journal of Fish Aquatic Science, 11: 1-5. DOI: 10.4194/trjfas.2011.0101

Burt, S.A., Vlielader, R., Haagsman, H.P. \& Veldhuizen, E.J.A. (2005). Increase in activity of essential oil components carvacrol and thymol against Escherichia coli 0157:H7 by addition of food stabilizers. Journal of Food Protection, 68: 919-926.

Careche, M., Mazo, M.L.D. \& Fernández-Martín, F. (2002). Extractability and thermal stability of frozen hake (Merluccius merluccius) fillets stored at - 
10 and $-30^{\circ} \mathrm{C}$. Journal of the Science of Food and Agriculture, 82: 1791 1799. DOI: $10.1002 /$ sfa. 1257

Çelik, M. (2008). Seasonal changes in the proximate chemical compositions and fatty acids of chub mackerel (Scomber japonicus) and horse mackere (Trachurus trachurus) from the north eastern Mediterranean Sea. International Journal of Food Science and Technology, 43:933-938. DOI: $10.1080 / 10498850.2011 .621583$

Çoban, Ö.E. (2012). Evaluation of essentıal oils as a glazing material for frozen rainbow trout (Oncorhynchus mykiss). Journal of Food Processing and Preservation, 1-7. DOI: 10.1111/j.1745-4549.2012.00722.x

Du, W., Roberto, J., Avena-Bustillos, R.J., Hua, S.S.T. \& McHugh, T.H. (2011).

Antimicrobial volatile essential oils in edible films for food safety. In A. MèndezVilas (Ed.), Science against microbial pathogens: communicating current research and technological advances, 1224-1134

Duan, J., Cherian, G. \& Zhao, Y. (2010). Quality enhancement in fresh and frozen lingcod (Ophiodon elongates) fillets by employment of fish oil incorporated chitosan coatings. Food Chemistry, 119:524-532. DOI: 10.1016/j.foodchem.2009.06.055

Dyer, W.J., Fench, H.V. \& Snow, J.M. (1950). Proteins in fish muscle 1.Extraction of protein fraction in fresh fish. Journal of the Fisheries Research Board of Canada, 7, 585. DOI: 10.1139//47-052

Erkan, N. \& Bilen, G. (2010). Effect of essential oils treatment on the frozen storage stability of chub mackerel fillets. Journal für Verbraucherschutz und Lebensmittelsicherheit, 5:101-110. DOI: $10.1007 /$ s00003-009-0546-6

Geirsdottir, M. Hlynsdottir, H. Thorkelsson, G. \& Sigurgisladottir, S. (2007) Solubility and viscosity of herring (Clupea harengus) proteins as affected by freezing and frozen storage. Journal of Food Science, 72(7): 376-380. DOI:10.1111/j.1750-3841.2007.00471

Gimenez, B., Gomez-Guillen, M.C., Perez-Mateos, M., Montero, P. \& MarquezRuiz, G. (2011). Evaluation of lipid oxidation in horse mackerel patties covered with borage-containing film during frozen storage. Food Chemistry. 124: 1393-1403. DOI: 10.1016/j.foodchem.2010.07.097

Haard, N.F. (1992). Control of chemical composition and food quality attributes of cultured fish. Food Research International, 25: 289-307. DOI: 0.1016/0963-9969(92)90126-P

Hurling, R. \& McArthur, H. (1996). Thawing, refreezing and frozen storage effects on muscle functionality and sensory attributes of frozen cod (Gadus morhua). Journal of Food Science, 61 (6):1289-1296. DOI: 10.1111/j.1365-2621.1996.tb10981.x

Janjarasskul, T. \& Krochta, J. M., (2010). Edible Packaging Materials. Annual Review of Food Science Technology, 1: 415-48. DOI: 10.1146/annurev food .080708.100836

Keyvan, A., Moini, S., Ghaemi, N., Haghdoost, A.A., Jalil, S. \& Pourkabir, M., (2008). Effect frozen storage time on the lipid deterioration and protein denaturation during Caspian Sea white fish (Rutilus frisi kutum). Journal of Fisheries and Aquatic Science., 3, 404-409. DOI: $10.3923 /$ jfas.2008.404.409

Kilincceker, O., Dogan, I.S. \& Kucukoner, E. (2009). Effect of edible coatings on the quality of frozen fish fillets. LWT - Food Science and Technology, 42:868-873. DOI: 10.1016/j.Iwt.2008.11.003

Laemmli, U.K. (1970). Cleavage of stuctural proteins during the assembly of the head of bacteriophage T4. Nature, 277: 680-685. DOI: $10.1038 / 227680 \mathrm{a} 0$

Laughton, M.J., Halliwell, B., Evans, P.J. \& Hoult, J.R. (1989). Antioxidant and prooxidant actions of the plant phenolics quercetin, gossypol and myricetin. Effects on lipid peroxidation, hydroxyl radical generation and bleomycin-dependent damage to DNA. Biochemical Pharmacology, 38 , 2859-2865. DOI:10.1016/S1360-1385(97)01018-2

LeBlanc, E.L.\& LeBlanc, R.J. (1989). Separation of cod (Gadus morhua) fillet proteins by electrophoresis and HPLC after various frozen storage treatments. Journal of Food Science, 54:827-834.

Losada,V., Pineiro, C., Barros-Vela'zquez, J. \& Aubourg, S.P. (2005). Inhibition of chemical changes related to freshness loss during storage of horse mackerel (Trachurus trachurus) in slurry ice Food Chemistry, 93, 619-625.
Lowry, O.H., Rosebrough, N.J., Farr, A.L. \& Randall, R.J. (1951). Protein Measurement with the Folin Fhenol Reagent. Journal of Biological Chemistry, 193, 265-275.

Matsumoto, J.J. (1980). Chemical deterioration of muscle proteins during frozen storage. In J.R Whitaker \& M. Fujimaki (Eds.), Chemical Deterioration of Proteins: 95-124. American Chemical Society ACS, Washington, DC

Mennen, L.I., Walker, R., Bennetau-Pelissero, C. \& Scalbert., A. (2005). Risks and safety of polyphenol consumption. American Journal of Clinical Nutrition, 81, 326-329.

Motalebi, A. A., Hasanzati Rostami, A., Khanipour, A. A. \& Soltani., M. (2010). Impacts of whey protein edible coating on chemical and microbial factors of gutted kilka during frozen storage. Iranian Journal of Fisheries Sciences, 9(2), 255-264.

Montecchia, C.L., Roura, S.I., Roldan, H., Perez-Borla, O. \& Crupkin,M. (1997) Biochemical and physicochemical properties of actomyosin from frozen pre- and post-spawned hake. Journal of Food Science, 62(3), 491-495. DOI: 10.1111/j.1365-2621.1997.tb04413.x

Ojagh, S.M., Rezaei, M., Razavi, S.H. \& Hosseini, S.M.H. (2009). Effect of chitosan coatings enriched with cinnamon oil on the quality of refrigerated rainbow trout. Food Chemistry, 120,193-198. DOI: 10.1016/j.foodchem.2009.10.006

Owusu-Ansah, Y. J. \& Hultin, H. O. (1986).Chemical and physical changes in red hake fillets during frozen storage. Journal of Food Science, 51, 14021406.

Özden, Ö. (2010). Micro, macro mineral and proximate composition of Atlantic bonito and horse mackerel; a monthly differentiation. International Journal of Food Science and Technology, 45, 578-586.

Paulus, K., Zacharias, R., Robinson, L. \& Geidel, H. (1979). Kritische betrachtungen zur "bewertenden prüfung mit skale als einem wesentlichen verfahren der sensorischen analyse. LebensmittelWissenschaft und Technologie, 12(1), 52-61.

Pearson, D.A., Frankel, E.N., Aeschbach, R. \& German, J.B. (1997). Inhibition of endothelial cell-mediated oxidation of lowdensity lipoprotein by rosemary and plant phenolics. Journal of Agricultural Food Chemistry, 45, 578-582. DOI: 10.1111/j.1365-2621.2009.02170

Rhim, J.W., Gennadios, A., Handa, A., Weller, C.L. \& Hanna, M.A., (2000). Solubility, tensile, and color properties of modified soy protein films. Journal of Agricultural Food Chemistry, 48, 4937-494. DOI: 10.1021/jf0005418

Rodriguez-Turienzo, L., Cobos, A., Moreno, V., Caride, A., Vieites, J.M. \& Diaz, O. (2011). Whey protein-based coatings on frozen Atlantic salmon (Salmo salar): Influence of the plasticiser and the moment of coating on quality preservation. Food Chemistry, 128(1), 187-194. DOI: 10.1016/j.ifset.2011.12.003

Saeed, S. \& Howell, N.K. (2002). Effect of lipid oxidation and frozen storage on muscle proteins of Atlantic mackerel (Scomber scombrus). Journal of Science Food Agriculture, 82, 579-586. DOI: 10.1002/jsfa.1080

Sathivel, S. (2005). Chitosan and protein coatings affect yield, moisture loss, and lipid oxidation of pink salmon (Oncorhynchus gorbuscha) fillets during frozen storage. Journal of Food Science, 70(8), 455-459. DOI: $10.1111 / j .1365-2621.2005 . t b 11514 . x$

Sathivel, S., Liu, Q., Huang, J. \& Prinyawiwatkul, W. (2007). The influence of chitosan glazing on the quality of skinless pink salmon (Oncorhynchus gorbuscha) fillets during frozen storage. Journal of Food Engineering, 83, 366-373. DOI:10.1016/j.jfoodeng.2007.03.009

Seydim, A.C. \& Sarikus, G. (2006). Antimicrobial activity of whey protein based edible films incorporated with oregano, rosemary and garlic essential oils. Food Research International, 39(5), 639-644. DOI:10.1016/j.foodres.2006.01.013

Siddaiah, D., Reddy, G.V.S. \& Chandrasekhar, T.C. (2001). Changes in lipids, proteins and kamaboko forming ability of silver carp (Hypophthalmichthys molitrix) mince during frozen storage. Food Research International, 34, 4753 
Simeonidou, S., Govaris, A. \& Vareltzis, K. (1997). Effect of frozen storage on the quality of whole fish and fillets of horse mackerel (Trachurus trachurus) and Mediterranean hake (Merluccius mediterraneus). Zeitschrift für Lebensmittel-Untersuchung und -Forschung, 204, 405-410. DOI: $10.1007 / \mathrm{s} 002170050102$

Stuchell, Y.M. \& Krotcha, J.M. (1995). Edible coating on frozen king salmon effect of whey protein isolate and acetylated monoglycerides on moisture loss and lipid oxidation. Journal of Food Science, 60: 28-31. DOI: 10.1111/j.1365-2621.1995.tb05599

Tarladgis, B., Watts, B.M., Yonathan, M. \& Dugan, L.J. (1960). Distilation Method for Determination of Malonaldehyde in Rancidity Food. Journal of American Oil Chemists' Society, 37(1), 44-48.

Undeger, Ü., Basaran, A., Degen, G.H. \& Basaran N. (2009). Antioxidant activities of major thyme ingredients and lack of (oxidative) DNA damage in V79 Chinese hamster lung fibroblast cells at low levels of carvacrol and thymol. Food Chemistry Toxicology, 47, 2037-2043.

DOI: 10.1111/j.1365-2621.1995.tb05599

Undeland, I., Kelleher, S.D., Hultin, H.O., McClement, J. \& Thongraung, C.H. (2003). Consistency and solubility changes in herring (Clupea harengus) light muscle homogenates as a function of $\mathrm{pH}$. Journal of Agricultural and Food Chemistry, 51, 3992-3998.

DOI: $10.1021 / \mathrm{jf0} 210932$

Vareltzis, K., Koufidis, D., Graviilidou, E., Papavergou, E. \& Vasiliadou, S. (1997). effectiveness of a natural Rosemary (Rosmarinus officinalis) extract on the stability of filleted and minced fish during frozen storage. Zeitschrift fur Lebensmittel- ntersuchung und-Forschung, 205, 93-96. 